\title{
Social Media Adoption in SMEs Impacted by COVID-19: The TOE Model*
}

\author{
Mohamad Irhas EFFENDI ${ }^{1}$, Dyah SUGANDINI², Yuni ISTANTO
}

Received: August 01, 2020 Revised: September 30, 2020 Accepted: October 15, 2020

\begin{abstract}
The purpose of the research is to analyze the behavioral intention to adopt social media in SMEs affected by the COVID-19 crisis, based on the TOE Model. This study uses the TOE framework as a theoretical basis. This research is important because COVID-19 has destroyed most of the SMEs, and SMEs are exposed to social media technology to market their products. The success of social media adoption has helped SMEs to be able to rise from adversity. Respondents in this study were 250 SMEs in the Special Region of Yogyakarta, Indonesia. The data analysis technique used is structural equation modeling with AMOS. The results of this study indicate that SMEs affected by the COVID-19 crisis have a high awareness of social media and have a high intention to adopt social media as a way to market their products and connect with customers. The intention to adopt social media is significantly influenced by the technological context, organizational context, environmental context, and social media awareness. The findings of this study suggest that in times of crisis due to the COVID-19 pandemic, the Government support is needed. The Government needs to open services for SMEs whose businesses are affected by the pandemic.
\end{abstract}

Keywords: Behavior Intention, Technology, Organization, Environment

JEL Classification Code: M31, M15, L20, O32

\section{Introduction}

The Corona Virus Pandemic (COVID-19) has a significant impact on the small- and medium-sized enterprises (SME) in Indonesia. The increasingly massive corona outbreak

\footnotetext{
*Acknowledgements:

We would like to thank the Ministry of Research and Technology / Deputy of the National Research and Innovation Agency for strengthening research and development that has funded this research. This research was funded by the Higher Education Excellence Basic Research Grant / PDUPT in 2020.

${ }^{1}$ First Author. Lecturer of Management Department, Economic and Business Faculty, Universitas Pembangunan Nasional Veteran Yogyakarta, Indonesia. Email: m irhaseffendi@upnyk.ac.id

${ }^{2}$ Corresponding Author. Lecturer of Management Department, Economic and Business Faculty, Universitas Pembangunan Nasional Veteran Yogyakarta, Indonesia [Postal Address: Jl. SWK Jl. Ring Road Utara No.104, Ngropoh, Condongcatur, Kec. Depok, Kabupaten Sleman, Daerah Istimewa, Yogyakarta 55283, Indonesia] Email: dini@upnyk.ac.id

${ }^{3}$ Lecturer of Management Department, Economic and Business Faculty, Universitas Pembangunan Nasional Veteran Yogyakarta, Indonesia. Email: yuni.istanto@upnyk.ac.id

(c) Copyright: The Author(s)

This is an Open Access article distributed under the terms of the Creative Commons Attribution Non-Commercial License (https://creativecommons.org/licenses/by-nc/4.0/) which permits unrestricted non-commercial use, distribution, and reproduction in any medium, provided the original work is properly cited.
}

eventually disrupted the marketing process at a critical point. SMEs are the most affected by the coronavirus pandemic. The SME sector can no longer be a buffer for the economy as it was during the economic and financial crises of 1998 and 2008. When Indonesia experienced a monetary crisis in 1998, SMEs could still be a buffer for the national economy, absorbing the workforce, and moving the economy. In 2008 during the global financial crisis, SMEs remained strong in sustaining the economy. However, SMEs still could not withstand the crisis caused by COVID-19. The effects of the previous economic and financial crisis were more localized in specific sectors. COVID-19 has caused SMEs to become the most vulnerable sector of the economic crisis. The Jakarta Stock Exchange reported that the price of the Composite Stock Index (CSPI) experienced the worst decline in the last decade, reaching $5 \%$. At the same time, the rupiah continues to weaken against the U.S. dollar.

The Ministry of Cooperatives and SMEs received complaints from 1,417 SMEs related to the COVID-19 impact since March 2020. This number will still increase in line with the personal reports of business actors, as well as based on the results of the provincial, district, and city government data collection. Of the interim figures, some constraints experienced by businesses during the pandemic accounted for $68 \%$ complaining of sales and falling demand; 
$14 \%$ complained about difficulty to raise capital during the pandemic; $9 \%$ of SME business operators complained that distribution and operations are late; $5 \%$ complained about the difficulty of getting raw materials, and the remaining $4 \%$ complained about stunted production. The corona outbreak resulted in restrictions on community movements and the number of employees working through the method Work from Home and the stay at the home movement. The COVID-19 pandemic caused the Government to suggest social distancing. Social distancing, according to Reluga (2010), is an aspect of human behavior to reduce the level of contact with others to reduce the transmission of diseases. Social distancing is very useful when there is no vaccine and to delay epidemics until the vaccine is widely available. However, social distancing has a severe impact on the operations and marketing of SMEs in Indonesia.

On the other hand, along with the widespread implementation of social distancing, online shopping is also increasing because it is the main alternative for many people. Social distancing forces small companies in Indonesia in critical times to use an online marketing-based approach. SMEs must also provide facilities for customers to continue shopping offline for their basic needs, especially for grocery retail stores. Digital media has become the most effective and efficient choice for communicating with communities and also customers. Digitalization is the answer to the quarantine policy so that SMEs can still market their products. E-marketing makes it easy for SMEs to provide accurate, attractive, and useful information to their customers. Unfortunately, many SMEs in Indonesia are not yet familiar with using digital marketing (Sugandini et al., 2019). Research conducted by Sugandini et al. (2018) shows that SMEs in Indonesia do not have human resources with adequate technical skills. SMEs also think that the cost of using social media is very high.

Innovative marketing, according to Larkina et al. (2018), is a determinant of the success of interactions with potential consumers. Creative marketing can also respond to the changing speed of customer desires and market demands. The ability of marketing managers is needed to find innovations that can respond to changes in the rate of information technology and the tastes of new customers and ensure the ability of consumers to pay. E-business has become a necessity for dealing with the crisis caused by COVID-19. This research aims to explain why SMEs in Indonesia cannot quickly respond to Internet-based marketing to maintain their product marketing. Several factors observed in this study were obtained by in-depth research of SMEs affected by COVID-19. The pre-survey results show that operationally Indonesian SMEs that do not rely on imported raw materials are not so affected. Raw materials are still accessible. Human resources at SMEs are usually also handled directly by the owner and his family.
But the decline in sales has caused these SMEs to have to close down their businesses eventually. The decline in sales changes SMEs from traditional marketing to using social media. The barriers to adoption are also strengthened in the opinions of Alotaibi (2018) and Hopp and Gangadharbatla (2016), which state that barriers to adopting social media for SMEs can be categorized in three ways, namely, organizations, social media, and individuals (employees).

Research on the successful adoption by SMEs of social media is essential because the success of SMEs in adopting information technology can have an impact on the sustainability of SMEs and can further sustain the economy of the country. The basic theory used in this study is the Technology environment model from Tornatzky and Fleischer (1990). TOE explained that the successful adoption of SMEs' technology is influenced by technological, organizational, and environmental factors (Chiu et al., 2017). Piaralal et al. (2015 and Chong and Olesen (2017) stated that the TOE framework has proven to be quite useful in analyzing the successful adoption of information technology in SMEs (Awa et al., 2017). Kamenga and Alexander (2017) show that small businesses may have to change the way they do business to adopt digital technology. Changing company practices is a big challenge that must be faced by small businesses. The critical role of social media for SMEs requires further analysis. (He et al., 2014); research on social media adoption is still critical (Kim et al., 2013). The emergence of social media allows small businesses to gain access to resources that have been dominated by large companies (Kim et al., 2013). Social media is an opportunity for small businesses to compete beyond their local markets. Another problem related to studies related to social media is that most reviews are carried out in developed countries (Kim et al., 2013; Jones et al., 2015). Research on the adoption of information technology innovation is still lacking in developing countries (Ainin et al., 2015).

\section{Literature Review}

\subsection{Technology-Organization-Environment (TOE) Model}

The conceptual framework proposed in this study is the Technology-Organization-Environment (TOE) model, which was introduced by Tornatzky and Fleischer (1990); Chiu et al., (2017). The TOE framework is also used by ElHaddadeh (2019) to analyze the adoption of the dynamics of innovation in cloud computing in SMEs by observing factors of senior managers' perceptions, information technology capabilities, risk perceptions, and barriers to adoption. TOE is used as a basis for ensuring the process of confirmation of innovation through organizational identification in adopting technological innovation (Kim, 2015). 
The TOE framework is useful in investigating various contexts of innovation, such as e-commerce, e-business, and entrepreneurial resource planning to estimate the readiness of information technology from SMEs (Awa et al., 2017). The TOE framework has also been used generally as a theory to test technology adoption by SMEs (Sabi et al., 2017; El-Haddadeh, 2019). TOE has also proven to be the chosen framework in understanding technology adoption (Sugandini et al., 2018, 2019), and the value creation that comes with new technology (Makame et al., 2014).

\subsection{Social Media Awareness}

Alshehri (2019) defines social media as a web-based service that allows individuals to build public profiles, articulate users when sharing connections with others, and view a list of links made by other users in a system. Alshehri (2019) defines consciousness as the subjective condition of a person's existence to realize something, both within oneself or outside of himself. Social media awareness is a prerequisite for further use of social media. Awareness refers to knowing and understanding more about something that happens in the world or around someone. Oyekan (2008) identified a lack of awareness as one of the problems that contradicted the use of social media. Hew (2011) states that social media awareness is the primary determinant of informal scientific communication. Alencar (2016) made a significant contribution from the results of his research on the meaningful relationship between social media awareness and social media adoption for informal scientific communication. Bugshan (2019) states that media awareness has become a means of diffusion and improvement of information. Praveena and Thomas (2014), Shen (2015) agree that awareness is an essential factor influencing the intention to continue to adopt web technology.

H1: Social media awareness influences intention to adopt social media.

\subsection{Technological context}

The technological context focuses on internal and external technology that is beneficial for companies that discuss the technical knowledge needed to apply social media (Matikiti et al., 2018); (Jeyaraj et al., 2006). Rogers' diffusion theory of innovation (2003) and TOE have also been commonly used in recent years in the field of information technology, such as website adoption, cellular technology, and Internet adoption in small and medium trade (Chiu et al., 2017).

\subsubsection{Perceived Relative Advantage}

The technological factors proposed by Rogers (2003) are essential in influencing adoption decisions. Rogers (2003) defines relative advantage as a personal point of view that assumes that innovation is better than existing technology. Chong and Olesen (2017) state that relative advantage consistently influences the adoption of innovation. Chandra and Kumar (2018) explain the role of technological relative advantage factors in influencing the adoption of augmented reality in organizations for purposes of e-commerce. Organizations will adopt technological innovation if it can bring benefits to the organization both in organizational performance and economically (Nedbal \& Stieninger, 2014; Oliveira et al., 2014).

\subsubsection{Perceived Complexity}

Chong and Olesen (2017) define complexity as the extent to which new technological innovations are difficult to use. Their research results show that complexity harms the adoption of information technology in small businesses. Zhai (2010), Wu, and Chuang (2009) also show that complexity influences e-commerce adoption. Porter (2012) shows that individuals with confidence in excellent performance abilities will easily use new technology based on the experience they have. The perception of the complexity of the use of information technology is usually associated with the rejection of users on social websites that are antecedents of e-commerce adoption (Ali et al., 2015). El-Gohary (2012) also concluded that complexity influences social media marketing adoption decisions. Nguyen et al. (2020) investigated the influence of factors on e-invoicing at the start of the adoption stage in Vietnam. Tahar et al. (2020) show that perceived ease of use positively affects attitudes and behavior of e-Filing adoption in Indonesia.

\subsubsection{Perceived Compatibility}

The diffusion of innovation (DOI) theory defines compatibility as the compatibility of innovation with existing systems in an organizational environment. Perceived compatibility is the user's perception of the consistency of new technology with existing values, experience, and potential needs (Rogers, 2003); (Oliveira et al., 2014). El-Gohary (2012) shows that compatibility also makes it easy for SMEs to adopt digital marketing tools. Ghobakhloo et al. (2011) found that compatibility affects the ability of organizations to develop their business systems. Ahmad and Agrawal (2012); Nguyen et al. (2020) report the lack of compatibility between existing systems and emerging technologies, such as the new generation of digital technology, making information technology challenging to adopt.

H2: Technological context influences social media awareness. 


\subsection{Organizational Context}

He et al. (2014) stated that research on social media in small businesses is fundamental and needs to be studied further (Kim et al., 2013). The emergence of social media makes it easy for small businesses to obtain resources into the dominance of large companies (Kim et al., 2013). SMEs have the opportunity to compete outside the market they currently occupy (He et al., 2014). Information technology helps SMEs to cut costs by improving their internal processes, faster communication with customers, and distributing their products better through online (Ainin et al., 2015). The main benefits of adopting sophisticated I.T. include reducing costs, increasing productivity, increasing system integration, providing a collaborative environment, and increasing overall competitiveness. MacGregor and Vrazalic's (2005) study findings show that the lack of technical skills and knowledge of I.T. as well as the high cost of implementing I.T. are significant barriers to e-commerce adoption (El-Gohary, 2012). Ifinedo (2011) found that what caused SMEs to be reluctant to accept Internet technology and e-business was commitment/management support and external pressure, which were significant predictors of I.T. acceptance.

\subsubsection{Employee Skills}

Employee skills to deal with technological complexity is one factor that significantly influences adoption (Bharati \& Chaudhury, 2015). MacGregor and Vrazalic (2005) show that a lack of technical skills and I.T. knowledge, as well as high implementation costs, are significant barriers to e-commerce adoption. Bharati and Chaudhury (2015) also showed that skills in using information technology affect the speed of technology adoption in organizations.

\subsubsection{Cost Perception}

Another critical factor that inhibits the adoption and use of I.T. is high technology costs. Lack of finance is one of the two main obstacles for organizations to adopt I.T. The cost of procuring information technology that is perceived to be high by SME owners will slow down technology adoption (Awa et al., 2015). Potluri and Vajjhala (2018) analyzed the opportunities and challenges faced in adopting and utilizing Web 3.0 technology in developing countries. The results show that financial constraints of SMEs significantly affect adoption.

\subsubsection{Top Management Support}

Top management support can influence web 2.0 adoption (Newbury et al. 2014), and influence e-commerce adoption attitudes, influence the adoption of e-commerce-commerce and Internet technology (Dahnil et al., 2014); Matikiti et al., (2012). Matikiti et al. (2018) also show that top management support influences attitudes toward the adoption of social media marketing. This research is consistent with the findings of Wanyoike et al. (2012) and El-Gohary (2012). Dahnil et al. (2014) show that top management support can make all the resources needed for e-commerce implementation available. Hwang et al. (2012) concluded that the success of information systems is dependent on the support of the organization's top management, as well as training. Fitriati and Mulyani (2015) showed the importance of senior management support and the level of sophistication of information systems in organizations in Indonesia, determining the success of information systems.

H3: Organizational context influences social media awareness.

\subsection{Environmental Context}

The business environment is the main force that can encourage or hinder an organization from adopting innovation (Rogers, 2003). The external environment is the arena in which the organization runs its business. The two central environmental pressures in the adoption of SME e-commerce are pressure from trading partners such as suppliers and customers and competitive pressure. Other essential factors are the level of national infrastructure and government involvement in encouraging the adoption of e-commerce and supporting technology infrastructure such as access and quality of information technology consulting services (Ghobakhloo et al., 2011). On the other hand, the lack of regulatory support significantly influences technology adoption (Sutter, 2012).

\subsubsection{Competitive Advantage}

Aspasia and Ourania (2014) shows that more and more companies have adopted electronic communications in various e-marketing platforms for marketing activities. Social media has replaced marketing activities from conventional to digital-based (Ndekwa \& Katunzi, 2016). The environmental context related to competitors and business partners (Piaralal et al., 2015). The ecological context has useful in predicting the adoption of SMEs' information technology (Chiu et al., 2017). Awa et al. (2017) also explained that the environmental context influences the decision on the adoption of information technology. The Technology Acceptance Model developed by Alotaibi (2018) shows that the ecological context is essential for the successful use of information technology. Krasnov et al. (2018) show that world economic trends and the development of the business environment influence the adoption of innovations 
Mohamad Irhas EFFENDI, Dyah SUGANDINI, Yuni ISTANTO /

in marketing. The main drivers of information technology adoption are a competitive advantage and reducing costs and time and increasing productivity (Awa et al., 2017).

Bordonaba-Juste et al. (2012) concluded that the external environment mostly pressures companies to adopt e-business practices. Theodosiou and Katsikea (2012) also show factors that influence the intensity of e-business adoption, namely top management support, organizational learning ability, customer orientation, competitor orientation, culture, customer strength, and normative pressure. Organizations will more quickly adopt cloud computing and participate in using technology used by competitors because they face competitive pressures from competitors (Oliveira et al. 2014).

\subsubsection{Government Support}

Government support through legislation is one of the environmental factors that influence technology adoption in the TOE framework. Regulations established by the Government can motivate and prevent organizations from adopting technological innovations. When the Government issues special regulations requiring several companies to have strict control and testing tools for industrial safety, these government regulations tend to hamper adoption (Seethamraju, 2015). On the other hand, if government regulations can provide financial support, resources, and tax breaks, it will encourage organizations to adopt technological innovations (Tornatzky \& Fleischer, 1990). This regulation motivates these organizations to adopt Green information technology (Chen \& Chang, 2014).

\subsubsection{Environmental Uncertainty}

An environment full of uncertainty can harm the use of new technology. Environmental uncertainties occur when there are changes that are complex and fast. Organizations in a state of high uncertainty may not adopt new technology without the support of their infrastructure and clear operating standards. This uncertainty impacts the reluctance to adopt information technology (Chong \& Olesen, 2017). According to Mergel (2013), social media applications also have a high level of uncertainty because they are hosted and designed by an external third party.

H4: Environmental context influences social media awareness.

\section{Research Method}

This research is based on a survey of 250 SME respondents who were affected by COVID-19 in the Special Region of Yogyakarta, Indonesia. The number of respondents refers to the adequacy of the model established by Hair et al. (2018). Loehlin (1998) states that the minimum sample size needed to reduce bias in all types of SEM estimates is 200. The sample size for the maximum likelihood (ML) estimate must be at least $15 \mathrm{x}$ the number of observed variables (Stevens, 1996). A significant decrease in sales shows that SMEs were affected by COVID-19. Data was collected from handicraft SMEs, various business SMEs, and trade SMEs. In-depth interviews were conducted with Google Zoom. Most of the respondents are SMEs owners who also work as managers in their UKM. The survey was conducted online using Google forms. This research uses Structural Equation Modeling as a data analysis tool. The independent variables in this study are the technological context, organizational context, and environmental context. Indicators of technological context include the perception of relative advantage, complexity, and compatibility. The organizational context is shown by employee skills, high-cost perceptions, and top management support. The environmental context is measured by indicators of perception of competitive advantage, government support, and environmental uncertainty. Data analysis uses Structural Equation Modeling with AMOS.

\section{Results}

\subsection{Description of Research Respondents}

This study uses data taken from 250 SME respondents in the Special Region of Yogyakarta. Respondents are all SME owners as well as UKM leaders. The income during the year ranges from 100 million to 1 billion rupiahs. Respondents were mostly male (85\%). On average, each UKM has been operating for more than five years. The age of respondents is mostly above 50 years old.

\subsection{Validity and Reliability}

The reliability and validity test results show that all instruments used in the study are valid and reliable so that they can be used for further testing. The research instrument used to measure behavior intention to use social media was adapted from Tuten (2020). Social media awareness and intention to adopt social media was taken from Musa et al. (2015). The technological context, organizational context, and environmental context were borrowed from Tornatzky and Fleischer (1990); Awa et al., (2017); Chiu et al., (2017).

\subsection{Model Evaluation Using SEM-AMOS}

This study uses a Structural Equation Modeling-AMOS22 analysis tool involving 250 respondents. The results of data analysis showed that the chi-square was 165.490, DF: 88, probability level 0.064. CMIN / DF: 1.880. The Goodness of 
Fit Index: 0.92. Root Mean Square Error of Approximation: 0.079. Normed Fit Index: 0.90. Comparative Fit Index 0.94. The fit-index test results show that the behavior intention model to use social media with antecedents of technological context, organizational context, and environmental context can be accepted. Table 2 shows the C.R. values of each path $\geq 2$. The p-value of all paths $\leq 0.05$, so it can be concluded that all paths hypothesized are supported.

\section{Discussion}

The COVID-19 pandemic has made SME managers more aware of social media. This research shows that social media is increasingly believed to be adopted for the benefit of SME marketing. SME managers began looking for various information related to social media and its advantages for marketing products online. What benefits can be gained from using social media as a basis for the adoption of social media? Many small business managers at the time of COVID-19 were preoccupied with sharing about the use of social media, including the impacts and risks faced by using social media. SME managers are starting to become aware of the costs, and in crisis conditions, many SMEs are adopting unpaid social media. The use of outstanding social media helps SMEs under challenging times. SMEs also began to consider participation awareness. UKM is aware of the interaction that can be done through social media. SMEs are increasingly often in direct contact with their customers. Thus, the first hypothesis about the influence of social media awareness on the intention to adopt social media is supported. The study supports Hew (2011), which states that the level of social media awareness is a determinant of adoption. Alencar (2016) also says that there is a significant relationship between social media awareness and social media adoption (Bugshan, 2019).

The technological context, which is proxied from relative superiority, perceived complexity, and conformity perception, shows a significant positive effect on awareness of social media. During the COVID-19, SMEs are forced to use social media for marketing their products. Many SMEs who have felt the relative superiority of social media have become concerned with social media. SMEs' concern for social media starts to emerge when they need the means to offer their products, which so far have only been sold directly in the market. Work from home and the suggestion to stay at home means these SMEs can no longer sell their products directly. Based on this, the SMEs began to glance at the most likely Internet technology to be adopted. The choice of SMEs falls on social media technology. Social media is considered as an application that has advantages compared to offline marketing. Rogers (2003) shows that perceived superiority makes it easier to adopt information systems. Chong and Olesen (2017) also stated that relative excellence had an impact on the adoption of innovation. This statement was also supported by Chandra and Kumar (2018); Nedbal and Stieninger (2014); Oliveira et al. (2014).

Another factor that causes ease of adoption is complexity. Most SME managers also say that social media is not complicated when used, or is relatively easy to learn. This research supports Chong and Olesen (2017) opinion, which shows that the more difficult a technology will be, it will be challenging to adopt. Chong and Olesen (2017) also show that compatibility harms the adoption of information technology in SMEs. Perception is associated with user unfriendliness on social websites (Ali et al., 2015). This research shows that social media applications are easy to use and not as complicated as using other digital marketing applications.

This research shows that social media applications are easy to use and not as complicated as using other digital marketing applications. Social media applications have an impact on the awareness of social media. This research shows that using social media does not need to change the daily lives of SME managers because so far, the owners and employees are accustomed to using social media, like Whatsapp, Facebook, and Instagram.

Table 1: Results of analysis of relationships between variables

\begin{tabular}{|l|c|c|c|c|c|c|}
\hline Path & Estimate & Standardized Regression Weights & S.E. & C.R. & P & Hypothesis \\
\hline $\begin{array}{l}\text { Social media awareness } \rightarrow \\
\text { Intention to adopt SM }\end{array}$ & 0.753 & 0.886 & 0.094 & 7.991 & $* * *$ & Supported \\
\hline $\begin{array}{l}\text { Technological Context } \rightarrow \text { Social } \\
\text { media awareness }\end{array}$ & 0.644 & 0.272 & 0.127 & 5.085 & $* * *$ & Supported \\
\hline $\begin{array}{l}\text { Organizational Context } \rightarrow \text { Social } \\
\text { media awareness }\end{array}$ & 0.673 & 0.614 & 0.070 & 9.683 & $* * *$ & Supported \\
\hline $\begin{array}{l}\text { Environmental Context } \rightarrow \text { Social } \\
\text { media awareness }\end{array}$ & 0.872 & 0.663 & 0.112 & 7.802 & $* * *$ & Supported \\
\hline
\end{tabular}


Mohamad Irhas EFFENDI, Dyah SUGANDINI, Yuni ISTANTO /

During the COVID-19 pandemic, SME managers felt that the use of online applications was beneficial. Social media can quickly reach their consumers. The results of this study support Rogers (2003), Oliveira et al. (2014), and El-Gohary (2012), which shows that compatibility can facilitate SMEs to adopt information technology. Bharati and Chaudhury (2015) also show that employee skills are one of the factors that can influence adoption. They also show that the ability to apply information technology affects the speed of adoption in organizations. Awa et al. (2015) also showed that the perception of high information technology procurement costs affected the slow adoption.

This study uses respondent managers who are also SME owners. The COVID-19 pandemic shows that SME managers work together with their employees to prepare their online marketing infrastructure. Top management is increasingly aware of social media by seeking more knowledge about social media on resourcefulness. Adoption of social media has become easy for SMEs. The results of this study support Newbury et al. (2014), who state that managerial support influences adoption. Dahnil et al. (2014) also showed that top management support influenced the awareness of SME managers to adopt information technology. Matikiti et al. (2012) show that managerial support controls the implementation of e-commerce and the initiation of Internet technology. Matikiti et al. (2018) also showed that top management support affects awareness of social media marketing adoption.

The environmental context with indicators of competitive advantage, government support, and uncertainty also positively affects awareness of social media. The COVID-19 pandemic caused changes regarding SME marketing. Many SMEs experienced a fall in sales. Conditions of sales uncertainty have made SMEs managers more aware of the existence of social media. SMEs feel a high need to use social media. SMEs also think that marketing through social media can increase their competitive advantage. Marketing with social media allows SMEs to get consumers from outside the island and even abroad.

On the other hand, SMEs feel concerned if there is an increase in demand because these SMEs' conditions do not have excess production capacity. The problem is with imported raw materials, price fluctuations, and scarcity. SMEs must look at this issue as a challenge as well as an opportunity to use online marketing. The COVID-19 pandemic turned out to have forced SMEs to switch to digital marketing with all the consequences.

The results of this study support Aspasia and Ourania (2014) increasingly fierce competition for SMEs to use social media and revolutionize the way marketing activities are conducted (Ndekwa and Katunzi 2016; Piaralal et al., 2015). SME business competition in an environmental context can predict the adoption of information technology in developing countries (Chiu et al., 2017). Awa et al. (2017) and Alotaibi (2018) also show that a competitive environment is very influential in the successful adoption of social media. Krasnov et al. (2018) also stated that world economic trends and competition influenced marketing innovations.

The results of this study indicate that the Government has provided support to SMEs through the Go Online UKM government program, which aims to increase the number of SMEs who surf in cyberspace. This government support is carried out with various regulations that assist SMEs in marketing through social media. The Ministry of Cooperatives, SMEs, and the Ministry of Information Communication, together with e-commerce actors, initiated eight million UMKM Go Online. The Government also hopes to accelerate the transformation of SMEs in Indonesia towards the Digital Energy of Asia in 2020. The Government is assisting SMEs in using digital marketing applications, including social media. The Government also makes online promotion media for SMEs. The results of this study also show that SMEs felt government support. The results of this study support Seethamraju (2015), which states that government regulations can motivate SMEs to adopt the technology. Tornatzky and Fleischer (1990) state that the government's regulatory assistance to SMEs is financial support, resources, and tax relief (Chen \& Chang, 2014). The application uncertainty factor is also a reason for SMEs to be more aware of social media use. Most SMEs do not have adequate knowledge about applications in social media.

These SMEs managers currently only use social media that they understand. The survey results showed that SME managers did not feel that social media had high uncertainty. SME managers did not feel that social media because UKM managers' knowledge has not fully understood using social media applications. So, there are still many SME managers who are still trying to find out about social media's existence and its benefits for SME businesses. According to Chong and Olesen (2017), the uncertainty inherent in social media applications influences information technology adoption. Usually, social media applications have a high uncertainty level because the hosts are typically designed and managed by external parties (Mergel, 2013).

\section{Conclusions}

This study's results indicate that the TOE model proposed by Tornatzky and Fleischer (1990) is supported. This study suggests three hypotheses based on the TOE framework. The explanation, which states that technological aspects, organizational aspects, and environmental aspects affect social media awareness, are all supported. Behavioral intention to use social media models built in this study were 
also accepted because they have a good fit model. Most SMEs in Indonesia during the COVID-19 pandemic have experienced a fall in turnover of about $70 \%$. The presence of social media is expected to help drive the pace of business in SMEs so that the fallout from the COVID-19 pandemic can be overcome, and SMEs can again become supporters of the country's economy in a crisis.

\section{Contributions}

\subsection{Theoretical contributions}

This study justifies the importance of Rogers' (2003) theory of the diffusion of innovation and the TOE framework of Tornatzky and Fleischer (1990) in predicting behavioral intention to use social media in SMEs in developing countries, which are currently being hit by a crisis due to the COVID-19 pandemic. UKM, during this crisis, cannot afford to be a buffer for the economy in the country of Indonesia. SMEs are forced to do marketing and business activities via the Internet so that SMEs can continue to run their business processes and meet their customers' demands. This research also shows the importance of awareness of social media first before SME managers adopt social media. SMEs need to know in advance the existence of social media, how social media works, and how to use social media applications. A high level of awareness of social media can encourage the use of social media in these SMEs.

\subsection{Practical Contributions}

This research shows that SMEs in times of crisis due to the COVID-19 need support from the Government. The Government needs to open services for SMEs whose businesses are affected by the pandemic. The Government also needs to prepare programs to anticipate the impact of COVID-19, including proposing SME purchasing power stimulus and tax relaxation for SMEs. The Government also needs to assist SMEs in product promotion strategies by helping SMEs create engaging advertising content. Furthermore, SMEs need to improve their approach in coordinating and collaborating with their teams by utilizing online networks. Utilization of technology and tools professionals available today can be used by SMEs to determine work priorities, monitor, and evaluate their marketing.

\section{Limitations and Suggestions}

This research was conducted in Indonesia and can only be generalized to SMEs in countries with characteristics like Indonesia. This research was carried out during a crisis when the COVID-19 pandemic has threatened SMEs to go bankrupt. Further research is expected to conduct longitudinal studies by analyzing the adoption of information technology in the post-COVID-19 era. So, that they can provide a more precise explanation of differences in adoption during crises and during normal conditions. Furthermore, research should examine SMEs' readiness to adopt e-business more broadly, beyond social media. This research can be expanded by analyzing variables of organizational size, risk perception, and ownership type of e-business adoption.

\section{References}

Ahmad, I., \& Agrawal. (2012). An Empirical Study of Problems in The Implementation of Electronic Commerce in The Kingdom of Saudi Arabia. International Journal of Business and Management, 7(15), 70-80. https://doi.org/10.5539/ijbm. v7n15p70

Ainin, S., Parveen, F., Moghavvemi, S., \& Jaafar, N. I. (2015). Factors Influencing the Use of Social Media By SMEs and Its Performance Outcomes. Industrial Management \& Data Systems. 115. https://doi.org/10.1108/IMDS-07-2014-0205

Alencar, Amanda. (2016). Refugee Integration and Social Media: A Local and Experiential Perspective. Information Communication and Society. https://doi.org/10.1080/136911 8X.2017.1340500

Ali, N. M., Mat, N. K., \& Ali, N. M. (2015). The Conceptual Framework for E-Commerce Adoption Model. South African Journal of Information Management, 20(1). https://doi. org/10.5923/c.economics.201501.16

Alotaibi, R., Ramachandran, M., Kor, A., \& Hosseinian-Far, A. (2018). Factors Affecting Citizens' use of Social Media to Communicate with the Government: a Proposed Model. The Electronic Journal of e-Government, 14(1), 60-72.

Alshehri, O. (2019). Usage and Perceptions of Social Media Tools among Higher Education Instructor. International Journal of Information and Education Technology, 9(7). https://doi. org/10.18178/ijiet.2019.9.7.1252

Aspasia, V., \& Ourania, N. (2014). Social Media Adoption and Managers' Perceptions. International Journal on Strategic Innovative Marketing, 1, 61-73. https://doi.org/10.15556/ IJSIM.01.02.001

Awa, H., Ukoha, O. \& Emecheta, B. (2015). Integrating TAM, TPB, and TOE Frameworks And Expanding Their Characteristic Constructs For E-Commerce Adoption by SMEs. Journal of Science and Technology Policy Management, 6(1), 76-94. https://doi.org/10.1108/JSTPM-04-2014-0012

Awa, H. O., Ojiabo, O. U., \& Orokor, L. E. (2017). Integrated Technology-Organization-Environment (T-O-E) Taxonomies for Technology Adoption. Journal of Enterprise Information Management, 30(6), 893-921. https://doi.org/10.1108/JEIM03-2016-0079

Bharati, P., Zhang, W., \& Chaudhury, A. (2015). Better Knowledge with Social Media? Exploring The Roles of Social Capital and 
Organizational Knowledge Management. Journal of Knowledge Management, 19(3), 456-475. https://doi.org/10.1108/JKM-112014-0467

Bordonaba-Juste, V., Lucia-Palacios, L., \& Polo-Redondo, Y. (2012). The influence of organizational factors on e-business use: analysis of firm size. Marketing Intelligence \& Planning, 30(2), 212-229. https://doi.org/10.1108/02634501211211984

Bugshan, L. (2019). The role of social media in raising special needs awareness among Saudi people. Available from ProQuest Dissertations \& Theses Global: The Humanities and Social Sciences Collection.

Chandra, S., \& Khumar, K. N. (2018). Exploring Factors Influencing Organizational Adoption of Augmented Reality in E-commerce: Empirical Analysis UsingTechnologyOrganization- Environment Model. Journal of Electronic Commerce Research, 19(3), 237-265.

Chen, H. G., \& Chang, J. (2014). Exploring affecting factors on green IT adoption. In: Knowledge Management in Organizations (pp. 205-218). Springer International Publishing.

Chiu, C.-Y., Chen, S., \& Chen, C.-L. (2017). An Integrated Perspective of TOE Framework and Innovation Diffusion in Broadband Mobile Applications Adoption by Enterprises. International Journal of Management, Economics, and Social Sciences. 6(1), 14-39.

Chong, J. L. L., \& Olesen, K. (2017). A Technology-OrganizationEnvironment Perspective on Eco-effectiveness: A Metaanalysis. Australasian Journal of Information Systems, 21, 1-26. https://doi.org/10.3127/ajis.v21i0.1441

Dahnil, M. L., Marzuki, K. M., Langgat, J., \& Fabeil, N. F. (2014). Factors influencing SMEs adoption of social media marketing. Procedia - Social and Behavioral Sciences, 148, 119-126. https://doi.org/10.1016/j.sbspro.2014.07.025

El-Gohary, H. (2012). Factors Affecting E-Marketing Adoption and Implementation in Tourism Firms: An Empirical Investigation of Egyptian Small Tourism Organizations. Tourism Management. 33(5), 1256-1269. https://doi.org/10.1016/j. tourman.2011.10.013

El-Haddadeh, R. (2019). Digital Innovation Dynamics Influence on Organisational Adoption: The Case of Cloud Computing Services. Information Systems Frontiers. DOI. 10.1007/ s10796-019-09912-2

Fitriati, A., \& Mulyani, S. (2015). Factors that Affect Accounting Information System Success and Its Implication on Accounting Information Quality. Asian Journal of Information Technology, 14(5), 154-161. DOI: 10.3923/ajit.2015.154.161

Ghobakhloo, M., Arias-Aranda, D., \& Benitez-Amado, J. (2011). Adoption of e-commerce applications in SMEs. Industrial Management \& Data Systems, 111(8), 1238-1269.https://doi. org/10.1108/02635571111170785

Hair, J. F., Ringle, C. M., Gudergan, S. P., Fischer, A., Nitzl, C., \& Menicta, C. (2018). Partial least squares structural equation modeling based discrete choice modeling: an illustration in modeling retailer choice. Business Research. https://doi. org/10.1007/s40685-018-0072-4

He, W., Wang, F.-K., \& Zha, S. (2014). Enhancing social media competitiveness of small businesses: Insights from small pizzerias. New Review of Hypermedia and Multimedia, 20, 225-250. DOI: 10.1080/13614568.2014.889225

Hew, K. F. (2011). Students' and teachers' use of Facebook. Computers in Human Behavior, 27(2), 662-676. https://doi. org/10.1016/j.chb.2010.11.020

Hopp, T., \& Gangadharbatla, H. (2016). Novelty Effects in Augmented Reality Advertising Environments: The Influence of Exposure Time and Self-Efficacy. Journal of Current Issues \& Research in Advertising, 37, 113-130. https://doi.org/10.108 0/10641734.2016.1171179

Hwang, M., Lin, C., \& Lin, J. (2012). Organizational factors for successful implementation of information systems: Disentangling the effect of top management support and training. Paper presented at the Proceedings of 2012 Southern Association for Information Systems Meeting. Atlanta, GA, USA.

Ifinedo, P. (2011). Internet/e-business technologies acceptance in Canada's SMEs: An exploratory investigation. Internet Research. 21. https://doi.org/10.1108/10662241111139309

Jeyaraj, A., Rottman, J., \& Lacity, M. (2006). A review of the predictors, linkages, and biases in I.T. innovation adoption research. Journal of Information Technology, 21(1), 1-23. https://doi.org/10.1057/palgrave.jit.2000056

Jones, P., Packham, G., Beckinsale, M., Ramdani, B., Chevers, D., \& Williams, D. (2013). SMEs' adoption of enterprise applications: A technology-organization-environment model. Journal of Small Business and Enterprise Development, 20(4), 735-753. https://doi.org/10.1108/JSBED-12-2011-0035

Kamenga, R., \& Alexander, T. (2017). Digital Technology Adoption by African Entrepreneurs in Low-Income Communities. Paper presented at the $2^{\text {nd }}$ International Conference on Information and Communication Technology for Africa Development (ICT4AD'17). Douala, Cameroon.

Kim, H., Lee, I., \& Lee, C. (2013). Building Web 2.0 Enterprises: A Study of Small and Medium Enterprises in The United States. International Small Business Journal, 31, 156-174. https://doi. org/10.1177/0266242611409785.

Kim, W., Lim, H., \& Brymer, R. (2015). The Effectiveness of Managing Social Media on Hotel Performance. International Journal of Hospitality Management, 44, 165-171. https://doi. org/10.1016/j.ijhm.2014.10.014.

Krasnov, A., Nikonorov, V., \& Yanenko, M. (2018). Digital Platforms Based On Marketing Innovations: New Development Trends. SHS Web of Conferences, 44. https://doi.org/10.1051/ shsconf/20184400049.

Larkina, N., Ovcharenko, G., \& Tagaev, A. (2018). Evolution of the Theoretical Foundations for Marketing in the Context of The New Economy Formation. CBU International Conference Proceedings, 6, 288. https://doi.org/10.12955/cbup.v6.1171. 
Loehlin, J. C. (1998). Latent Variable Models: An Introduction to Factor, Path, and Structural Analysis. Mahwah, NJ: Lawrence Erlbaum Associates, Inc.

MacGregor, R., \&Vrazalic, L. (2005). A basic model of electronic commerce adoption barriers: A study of regional small businesses in Sweden and Australia. Journal of Small Business and Enterprise Development, 12(4), 510-527.https://doi. org/10.1108/14626000510628199.

Makame, W. H., Kang, J., \& Park, S. (2014). Factors influencing electronic commerce adoption in developing countries: The case of Tanzania. South African Journal of Business Management, 45(2), 83-96. https://doi.org/10.4102/sajbm.v45i2.126.

Matikiti, R., Afolabi, B. \& Smith, W. (2012). An Empirical Evidence on The Usage of Internet Marketing the Hospitality Sector in An Emerging Economy and Its Relationship to Profitability. International Review of Social Sciences and Humanities, 4(1), 181-197.

Matikiti, R., Mpinganjira, M., \& Roberts-Lombard. (2018). Application of The Technology Acceptance Model and The Technology-Organization-Environment Model to Examine Social Media Marketing Use in The South African Tourism Industry. Journal of Information Management, 20(1). https:// doi.org/10.4102/sajim.v20i1.790.

Mergel, I. (2013). Social Media Adoption and Resulting Tactics in the U.S. Federal Government. Government Information Quarterly, 30(2), 123-130. https://doi.org/10.1016/j. giq.2012.12.004

Musa, H., Mohamad, N., Rajiani, I., Hasman, N. S. B., \& Azmi, F.R. (2015). The Website Usage Among Private Sector: A Case of Malaysian Business Organization. European Journal of Business and Management, 7(6), 121-125.

Ndekwa, A. G. \& Katunzi, T. M. (2016). Small and Medium Tourist Enterprises and Social Media Adoption: Empirical Evidence from The Tanzanian Tourism Sector. International Journal of Business and Management, 11(4). 71-80. https://doi. org/10.5539/ijbm. v11n4p71

Nedbal, D., \& Stieninger, M. (2014). Exploring The Economic Value of A Cloud Computing Solution and Its Contribution To Green I.T. International Journal of Business Process Integration and Management, 7(1), 62-72. DOI: 10.1504/ IJBPIM.2014.060605.

Newbury, E., Humphreys, L., \& Fuess, L. (2014). Over the Hurdles: Barriers to Social Media Use in Extension Offices. Journal of Extension, 52(5), 8-10.

Nguyen, A. H.., Nguyen, T. P., \& Dang, G. T. T. (2020). Determinants of E-invoice Adoption: Empirical Evidence from Vietnam. Journal of Asian Finance, Economics and Business, 7(7), 311321. https://doi.org/10.13106/jafeb.2020.vol7.no7.311

Oliveira, T., Thomas, M., \& Espadanal, M. (2014). Assessing the determinants of cloud computing adoption: An analysis of the manufacturing and services sectors. Information and Management, 51(5), 497-510. https://doi.org/10.1016/j. im.2014.03.006.
Oyekan, G. L., \& Kamiyo, O. M. (2008). Effect of Nigerian Rice Husk Ash on Some Engineering Properties of Sandcrete Blocks and Concrete. Research Journal of Applied Sciences, 3, 345-351. http://medwelljournals.com/abstract/?doi=rjasci.2008.345.351

Piaralal, S. K., Nair, S. R., Yahya, N., \& Karim, J. A. (2015). An Integrated Model of The Likelihood and Extent of Adoption of Green Practices in Small and Medium-Sized Logistics Firms. American Journal of Economics, 5(2), 251-258. DOI: 10.5923/c.economics.201501.32

Porter, G. (2012). Mobile phones, livelihoods, and the poor in SubSaharan Africa: review and prospect. Geography Compass, 6(5), 241-259. https://doi.org/10.1111/j.1749-8198.2012.00484.x

Potluri, R, M., \& Vajjhala, N. R. (2018). A Study on Application of Web 3.0 Technologies in Small and Medium Enterprises of India. Journal of Asian Finance, Economics and Business, 5(2), 73-79. https://doi.org/10.13106/jafeb.2018.vol5.no2.73.

Praveena, K., \& Thomas, S. (2014). Continuance Intention to Use Facebook: A Study of Perceived Enjoyment and TAM. International Journal of Industrial Engineering and Management, 4(1), 24-29. DOI: 10.9756/BIJIEMS.4794.

Reluga, T. (2010). Game Theory of Social Distancing in Response to An Epidemic. Public Library Of Science Computational Biology, 6(5). https://doi.org/10.1371/journal.pcbi.1000793

Rogers, E. (2003). Diffusion of innovations ( $5^{\text {th }}$ ed.). New York, NY: The Free Press.

Sabi, H. M., Uzoka, F. M. E., Langmia, K., Njeh, F. N., \& Tsuma, C. K. (2017). A Cross-Country Model of Contextual Factors Impacting Cloud Computing Adoption at Universities in SubSaharan Africa. Information Systems Frontiers, 1-24. DOI: 10.1007/s10796-017-9739-1.

Seethamraju, R. (2015). Adoption of Software as A Service (SAAS) Enterprise Resource Planning (ERP) Systems in Small and Medium-Sized Enterprises. Information Systems Frontiers, $17(3)$.

Shen, G. C. (2015). How Quality of Life Affects Intention to Use Social Networking Sites: Moderating Role of Self-Disclosure. Journal of Electronic Commerce Research, 16(4), 276-289.

Stevens, J. (1996). Applied Multivariate Statistics for The Social Sciences $\left(3^{\text {rd }}\right.$ ed.). Mahwah, NJ: Lawrence Erlbaum.

Sugandini, D., Effendi, M. I., Istanto, Y., Arundati, R., \& Rahmawati, E. D (2019). Technology-Organization-Environment Model and Technology Acceptance Model in Adoption of Social Media Marketing on SMEs Tourism. Journal of Environmental Management and Tourism, 4(36), 878-885. https://doi. org/10.14505//jemt.10.4(36).19

Sugandini, D., Feriyanto, N., Muafi., Hadioetomo., \& Darpito, S. H. (2018). The Influence of Novelty Seeking Behavior and Autonomy toward New Product Trial in the Context of E-Business Learning: The Role of Mediation of Perceived Behavioral Control. Journal of Entrepreneurship Education, 21(3). 
Sutter, G. (2012). Response to the Consultation by The Ministry of Justice on The Draft Defamation Bill. European Journal of Law and Technology, 3(1).

Tahar, F., Riyadh, H. A., Sofyani, H., \& Purnomo, W. E. (2020). Perceived Ease of Use, Perceived Usefulness, Perceived Security and Intention to Use E-Filing: The Role of Technology Readiness. Journal of Asian Finance, Economics and Business, 7(9), 537-547. https://doi.org/10.13106/jafeb.2020.vol7. no9.537

Theodosiou, M., \& Katsikea, E. (2012). Antecedents and Performance of Electronic Business Adoption in The Hotel Industry. European Journal of Marketing, 4(1/2), 258-283. https://doi.org/10.1108/03090561211189329

Tornatzky, L., \& Fleischer, M. (1990). The Processes of Technological Innovation, Issues in Management Series. Lanham, MD: Lexington Books.
Tuten, D. L. (2020). Study of The Behavioral Intention to Use Social Media for Connection with The Government within Adults Using the UTAUT2 with Trust. Dissertation. https://e-resources. perpusnas.go.id:2076/docview/2385216038?accountid=25704

Wanyoike, D. M., Mukulu, E., \& Waititu, A. G. (2012). ICT Attributes as Determinants of E-Commerce Adoption by Formal Small Enterprises in Urban Kenya. International Journal of Business and Social Science, 3(23), 65-74.

Wu, I. L., \& Chuang, C. H. (2009). Analyzing Contextual Antecedents For The Stage-Based Diffusion Of Electronic Supply Chain Management. Electronic Commerce Research and Applications, 8(6), 302-314. https://doi.org/10.1016/j. elerap.2009.04.013

Zhai, C. (2010). Research on Post-Adoption Behavior of B2B E-Marketplace in China. Paper presented at the International Conference on Management and Service Science, Wuhan, China. 